\title{
Addition of Clinoptilolite In The Diet Reduces Uterine PMN Leukocytes And Open Days In Multiparous Lactating Dairy Cows Managed In A Mountain Tropical Pasture-Based System
}

\section{Franklin I Sinchi}

University of Cuenca: Universidad de Cuenca

Jenny F. Zuin

University of Cuenca: Universidad de Cuenca

Juan Pablo Garzón

Instituto Nacional de Investigaciones Agropecuarias

Gonzalo E. López

University of Cuenca: Universidad de Cuenca

Guido Calle

Centro Veterinario el Tambo

Fernando Quito

Ejercicio Libre

Diego A. Galarza

University of Cuenca: Universidad de Cuenca

Fernando P. Perea ( $\nabla$ ferromi9@gmail.com )

Universidad de Los Andes - Nucleo Rafael Rangel

\section{Research Article}

Keywords: clinoptilolite, dairy cows, uterine PMN leukocytes, reproductive performance, tropic

Posted Date: July 7th, 2021

DOl: https://doi.org/10.21203/rs.3.rs-625958/v1

License: (c) (i) This work is licensed under a Creative Commons Attribution 4.0 International License. Read Full License 


\section{Abstract}

This study was aimed to assess the effect of adding clinoptilolite in the diet on uterine health and reproductive performance in multiparous lactating dairy cows managed in a tropical pasture-based system above 2500 meters of altitude. Seventy-seven multiparous Holstein crossbred cows were allocated randomly into two groups: clinoptilolite supplemented cows (CLG, $n=42$ ) and nonsupplemented cows as control $(C G, n=35)$. Cows from CLG were supplemented with clinoptilolite from 30 days ( $50 \mathrm{~g} / \mathrm{cow} /$ day) before to 60 days after calving ( $200 \mathrm{~g} / \mathrm{cow} /$ day). Data were analyzed by general linear model, least squares means and chi-square test of SAS. In CLG cows, percentages of uterine PMN leukocytes $(P<0.0001)$ and proportion of subclinical endometritis $(P=0.0187)$ were lower than in $C G$. The interval calving to first corpus luteum was shorter $(P=0.0759)$ in $C L G$ than $C G$, and calving to first service interval was similar between treatments. Cows from CLG became pregnant 35 days earlier than CG cows $(P=0.0224)$. In conclusion, daily addition of clinoptilolite in the diet decreased the proportion of cows with subclinical endometritis and shortened the interval from calving to conception in lactating dairy cows.

\section{Introduction}

The transition period extends from 6 to 8 weeks before the end of gestation to the onset of lactation (Roche et al., 2017). In this phase, dairy cattle shift from a physiological stage of gestation at which does no milk is produced to one of non-gestation and intense milk production (Drackley, 1999). During the transition important hormonal and metabolic changes occur. Cows undergo a process of adaptation of the digestive system and high demand for nutrients due to fetal growth and milk synthesis (Zebeli et al., 2015). This physiological stage leads the cows to develop a state of oxidative stress and negative energy balance that significantly reduce voluntary dry matter intake and depresses the immune system (Sordillo, et al., 2009; Zebeli et al., 2015). This physiological, metabolic and nutritional context favors occurrence of numerous disorders such as ketosis, placental retention, abomasal displacement, and bacterial infections such as mastitis and endometritis. These conditions seriously affect productive and reproductive performance (Mulligan and Doherty, 2008), and cause death or culling of around $10 \%$ of affected cows (Pinedo et al., 2010).

Subclinical endometritis, an inflammatory disease of the reproductive tract, occurs very frequently in early postpartum in dairy cattle, because of the natural lacerations to superficial layer of the endometrium during calving and concomitant bacterial contamination of the uterus (Pascottini and LeBlanc, 2020). This situation is aggravated because the immune system is depressed during the peripartum period (Sordillo et al, 2009). Likewise, as this reproductive disorder occurs without clinical symptoms, it is not detected or treated, increasing the risk of developing more serious and difficult-to-treat uterine diseases (Bromfield et al., 2015). In addition, subclinical endometritis reduces reproductive efficiency (Quintela et al., 2017), increases the risk of cows being culled due to infertility (LeBlanc et al., 2002), and causes significant economic losses in the herd (Inchaisri et al., 2010). 
Considerable attention has been paid to nutritional management of cows during transition (Drackley and Cardoso, 2014; Lacasse et al., 2018). The addition of some supplements in diets to meet the nutritional needs of dairy cows in transition (Little et al., 2017), has contributed to reducing adverse effects during this critical period, and has favored milk production, reproduction and herd health (Osorio et al., 2016; Little et al., 2017).

Zeolites are natural minerals of volcanic origin described as crystalline hydrated aluminosilicates of alkali and alkaline earth cations having an infinite and open three-dimensional structure (Ivkovic et al., 2004). These chemical and physical characteristics confer catalytic, adsorption and ion exchange properties to zeolites (Valpotić et al., 2017). Among natural zeolites, clinoptilolite has been used as a feed supplement in zootechnical and biomedical fields with multiple beneficial effects (Valpotić et al., 2017). Addition of zeolite to a cattle diet modified the molar ratio of volatile fatty acids, decreasing acetate and increasing propionate, which may have a positive effect on energy efficiency (Urías-Estrada et al., 2017). Daily administration of $200 \mathrm{~g}$ of clinoptilolite to heifers from day 210 of gestation until the end of first lactation significantly increased body condition, serum concentration of glucose, milk production and reproductive variables (Karatzia et al., 2013). In a previous study, a greater proportion of multiparous Holstein cows supplemented with zeolite during the prepartum and postpartum (180 and $270 \mathrm{~g}$ respectively) achieved better body condition at 45 days postpartum, a follicle $\geq 10 \mathrm{~mm}$ was detected at 35 days postpartum and had a lower percentage of PMN leukocytes in the uterus compared to nonsupplemented group (Garzón et al., 2017).

The stimulating effect of clinoptilolite on the immune system has been also documented in several studies in cattle. For instance, in Holstein cows, addition of $3 \%$ clinoptilolite to the basal diet, from 4 weeks prior to expected parturition until 12 weeks after calving, increased milk production and decreased somatic cell count (Ural, 2014). In a recent study, supplementation of Holstein cows with $100 \mathrm{~g}$ of clinoptilolite daily from 7 months of pregnancy to day 75 postpartum (Đuričić et al., 2020), decreased the number of bacteria species causing mastitis and the number of affected quarters, as well the risk of intramammary infection compared to control group (Đuričić et al., 2017).

Information is scarce about the effect of zeolites on the reproductive activity in cattle. This study was aimed to evaluate the effect of adding clinoptilolite in the diet, from 30 days before to 60 days after calving, on uterine health and reproductive performance in multiparous lactating dairy cows managed in a pasture-based system above 2500 meters of altitude, in the southern of Ecuadorian Andean highlands.

\section{Materials And Methods}

\section{Study location}

This study was conducted in two commercial dairy farms located at 15 to 20 kilometers from the city of Cuenca, Azuay province, Ecuador, over 2500 meters above sea level. The area has an average temperature of $12.3^{\circ} \mathrm{C}$ and a rainfall of $1080 \mathrm{~mm}$ /year. These dairy farms had, in general, a similar 
management system, based on grazing, mechanical milking (twice daily) and a milk production of approximately $5000 \mathrm{~kg} /$ year.

\section{Animals, feeding and treatments}

Seventy-seven multiparous ( $4.3 \pm 1.3$ calving) Holstein cows with a body condition score (BCS) at calving of around 3 (2.95 \pm 0.08$)$ ( $1-5$ scale; Edmonson et al., 1989) were included in this study. All cows grazed a mix of fresh pasture consisting of perennial ryegrass (Lolium perenne), kikuyo (Cenchrus clandestinus), annual ryegrass (Lolium multiflorum), white clover (Trifolium repens), red clover (Trifolium pratense), which varied in different proportions according to farm and pastures where the cows grazed before and after calving. Cows were supplemented with $2 \mathrm{~kg} /$ day of concentrate from 30 days before calving, and with 4-6 kg/day after calving; also, cows had free access to mineral supplementation and water. The chemical composition of the basal diet and the concentrate are shown in Table 1.

Table 1. Chemical composition of the grass and concentrate used in the diet of multiparous lactating dairy cow

\begin{tabular}{lccccc}
\hline & \multicolumn{5}{c}{ Diet composition (\%) } \\
\hline Farm A & DM & EE & CP & CF & NFE \\
$\quad$ Grass & & & & & \\
$\quad$ dry period & 12.3 & 2.3 & 19.2 & 27.9 & 34.4 \\
$\quad$ lactation & 15.1 & 2.5 & 23.8 & 24.5 & 38.4 \\
Concentrate & 89.5 & 3.4 & 18.0 & 18.2 & 56.8 \\
Farm B & & & & & \\
Grass & & & & & \\
$\quad$ dry period & 10.4 & 2.4 & 18.2 & 27.5 & 33.5 \\
$\quad$ lactation & 15.5 & 2.5 & 23.6 & 23.9 & 38.4 \\
Concentrate & 89.1 & 3.4 & 17.5 & 17.6 & 54.5 \\
\hline
\end{tabular}

DM: dry matter; EE: ethereal extract; CP: crude protein; CF: crude fiber; NFE: nitrogen free extract

Cows were allocated randomly into two groups: clinoptilolite supplemented group (CLG, $n=42$ ) and control group ( $C G, n=35)$. The experiment was conducted from day 30 before the expected date of calving until day 60 postpartum. During prepartum period, CLG cows were supplemented with 50 g/cow/day of clinoptilolite (Captalin ${ }^{\circledR}$; La Colina Cia. Ltda., Cuenca, Ecuador) (www.lacolina.com.ec) and after calving with $200 \mathrm{~g} / \mathrm{cow} /$ day (following the manufacturer's recommendation). Clinoptilolite mixed with the concentrate was dispensed once a day in individual feeders. Cows with dystocia at calving, retention of foetal membranes, purulent or mucopurulent vaginal discharge after calving were excluded; hence, only cow clinically healthy were included in this study. According to farm, cows were distributed as follow, farm A ( $n=42)$ : CLG: 23 (4.2 \pm 1.5 calving; BCS: $3.08 \pm 0.35)$ and CG: 19 (4.3 \pm 1.5 calving; BCS: 
$3.0 \pm 0.30)$ cows; farm B $(n=35)$ : CLG: 19 (4.3 \pm 1.5 calving; BCS: $2.86 \pm 0.35)$ and CG: $16(4.4 \pm 2.0$ calving; BCS: $2.88 \pm 0.45)$ cows.

All animals were handled according to procedures approved by the Veterinary Medicine Career Committee, Faculty of Agricultural Science, University of Cuenca, Ecuador, and the research was conducted following Chap. 7.8 of the Terrestrial Animal Health Code - 2019@ OIE (08/07/2019), regarding to protection of animals used in scientific experiments.

\section{Uterine cytology}

Samples for endometrial cytology were collected in duplicate between days 35 and 45 (38.9 \pm 3.6 days) after calving as described by Garzón et al. (2017). The cytobrush (CE-Model, ZY-H001, Caricia, Ecuador) was rotated onto a microscope slide, and each smear was air-dried and fixed with ethyl alcohol to preserve cellular morphology. Endometrial samples were stained with Wright ${ }^{\circledR}$ staining (JQWRG-1 K0-00; Quimical, Ecuador), and observed under a microscope (Olympus CX31; Germany) at $\times 400$ magnification. Two hundred cells were counted to determine the proportion of PMN leukocytes in each slice. Cows with $\geq 10 \%$ of polymorphonuclear leukocytes were considered to have subclinical endometritis, as described by Kasimanickam et al. (2004).

\section{Ultrasonography}

The ovaries of each cow were examined by ultrasound once a week for three consecutive weeks, starting at day $19.6 \pm 3.6$ after calving, with a portable ultrasound scanner (Draminski, iScan, Poland) and a 7.5 $\mathrm{MHz}$ linear array transductor. The diameters of all detected follicles, day of detection, and size of the first corpus luteum were recorded. Follicles were categorized according to size into three classes: $<5 \mathrm{~mm}$ (class A), 5-10 mm (class B), $\geq 10 \mathrm{~mm}$ (class C).

\section{Reproductive variables}

Following a voluntary waiting period of 60 days after calving, estrous detection was performed by visual observation for $1 \mathrm{hr}$ twice a day (06:00 to 07:00 hr and 17:00 to 18:00 hr). In cows in estrus, artificial insemination was performed according to AM-PM rule, using frozen-thawed commercial bull semen with proven fertility. Pregnancy diagnosis was performed by rectal examination 45 days after artificial insemination in cows with non-return to estrus by an experienced veterinarian. The insemination dates and number of service per conception were recorded, and the following reproductive variables were calculated: intervals from calving to first corpus luteum, to first service and to conception, number of services per conception and first service conception rate.

\section{Statistical analysis}

Variables showing a skewed distribution according to the Shapiro-Wilks test were Log10 transformed. Intervals to first corpus luteum, to first service and to conception, number of service per conception, number and percentage of PMN (number of PMN leukocytes divide by total cell number $\times 100$ ) were 
analyzed by general lineal model of SAS (V 9.3; SAS Institute, Inc., Cary, NC, USA). Effects of treatment, farm, parity and treatment $\cdot$ farm interaction were included in the statistical model. Means were compared using least squares means test of SAS, and data were expressed as means \pm SEM. Proportion of cows with subclinical endometritis, first service conception rate and accumulated pregnancy at 45,60 , 75,90 days after calving were analysed by chi-square test of SAS. Statistical significance was considered as $P<0.05$, and $P$ values between 0.051 and 0.1 were considered as tendency.

\section{Results}

Body condition decreased as the postpartum days increased, without significant differences between experimental groups during the first 36 days after calving (Table 2). Numbers of follicles in different classes were similar between groups at all three ultrasound evaluations, with the exception of 5-10 mm (class $B$ ) follicles, whose number was significantly greater at the second ultrasound assessment in CG cows $(P=0.0077)$. The CLG group had the largest follicle at the first $(P=0.0325)$ and third $(P=0.0282)$ ultrasound examinations (Table 2). 
Table 2

Body condition and follicular characteristics (mean \pm SEM) in early postpartum in multiparous lactating dairy cows supplemented with clinoptilolite

\begin{tabular}{|c|c|c|c|c|c|}
\hline \multirow[t]{2}{*}{ Variables } & \multicolumn{2}{|l|}{ Treatment } & \multicolumn{3}{|l|}{ P-value } \\
\hline & Clinoptilolite $(n=42)$ & Control $(n=35)$ & $\mathrm{T}$ & $\mathbf{F}$ & $\mathrm{T} \times \mathrm{F}$ \\
\hline Body condition at calving & $2.92 \pm 0.08$ & $2.99 \pm 0.08$ & 0.4827 & 0.1027 & 0.3778 \\
\hline First ultrasound (days) ${ }^{1}$ & $20.0 \pm 3.8$ & $19.3 \pm 3.4$ & - & - & - \\
\hline body condition & $2.84 \pm 0.06$ & $2.88 \pm 0.06$ & 0.5707 & 0.3791 & 0.7702 \\
\hline class A follicles (n) & $7.7 \pm 2.0$ & $10.2 \pm 1.8$ & 0.2440 & 0.0254 & 0.6993 \\
\hline class B follicles (n) & $1.32 \pm 0.44$ & $1.40 \pm 0.40$ & 0.7754 & 0.0034 & 0.9684 \\
\hline class C follicles (n) & $1.20 \pm 0.21$ & $1.15 \pm 0.19$ & 0.9886 & 0.3714 & 0.8793 \\
\hline largest follicle (mm) & $14.2 \pm 1.3$ & $11.3 \pm 1.2$ & 0.0325 & 0.7896 & 0.3150 \\
\hline Second ultrasound (days) ${ }^{1}$ & $28.1 \pm 3.8$ & $27.6 \pm 3.7$ & - & - & - \\
\hline body condition & $2.82 \pm 0.07$ & $2.81 \pm 0.07$ & 0.9097 & 0.6799 & 0.6847 \\
\hline class A follicles (n) & $7.8 \pm 1.3$ & $7.3 \pm 1.4$ & 0.8661 & 0.4538 & 0.8275 \\
\hline class B follicles (n) & $0.98 \pm 0.24$ & $1.90 \pm 0.26$ & 0.0077 & 0.2506 & 0.3551 \\
\hline class C follicles (n) & $1.17 \pm 0.16$ & $1.05 \pm 0.16$ & 0.9001 & 0.1813 & 0.9172 \\
\hline largest follicle (mm) & $12.5 \pm 1.2$ & $11.4 \pm 1.3$ & 0.4897 & 0.7153 & 0.9248 \\
\hline Third ultrasound (days) ${ }^{1}$ & $34.1 \pm 3.0$ & $35.6 \pm 3.7$ & - & - & - \\
\hline body condition & $2.80 \pm 0.07$ & $2.68 \pm 0.08$ & 0.1874 & 0.3881 & 0.5306 \\
\hline class A follicles (n) & $8.0 \pm 1.9$ & $8.0 \pm 1.8$ & 0.8416 & 0.5881 & 0.7829 \\
\hline class B follicles ( $n$ ) & $1.03 \pm 0.33$ & $0.98 \pm 0.32$ & 0.5767 & 0.0357 & 0.1259 \\
\hline class C follicles (n) & $0.97 \pm 0.17$ & $0.73 \pm 0.16$ & 0.2865 & 0.4060 & 0.1947 \\
\hline largest follicle $(\mathrm{mm})$ & $14.7 \pm 1.5$ & $10.2 \pm 1.5$ & 0.0282 & 0.2489 & 0.6884 \\
\hline
\end{tabular}

T: treatment; F: farm; $T \times F$ : treatment $\times$ farm. ${ }^{1}$ Mean \pm SD.

Follicle categories: class A: $\leq 5 \mathrm{~mm}$; class B: $>5<10 \mathrm{~mm}$; class C: $>10 \mathrm{~mm}$.

Number and percentage of uterine PMN leukocytes were lower $(P<0.0001)$ in CLG than in CG (Fig. 1). For number and percentage of uterine PMN leukocytes there was no effect of farm, treatment - farm or parity.

The interval from calving to first corpus luteum was shorter $(P=0.0759)$ in CLG than CG, while calving to first service interval was similar between treatments. Likewise, cows from CLG became pregnant in 35 days earlier than $C G$ cows $(P=0.0224)$. Number of services per conception, first service conception rate, 
diameter of the corpus luteum, and proportion of cows with a corpus luteum at day 30 postpartum did not differ between groups (Table 3). Proportion of cows with subclinical endometritis was significantly lower $(P=0.0187)$ in CLG than in CG. For days open there was a treatment $\cdot$ farm interaction. On farm $A$, calving to conception interval was 18.1 days longer in CLG than in CG $(123.3 \pm 14.6$ v $105.2 \pm 15.7$ days, respectively; $P=0.3750)$, whereas in farm $B$ this interval was 86.2 days shorter in CLG than in CG $(96.5 \pm$ 16.1 v $182.7 \pm 17.5$ days, respectively; $P=0.0002$ ).

Table 3. Postpartum intervals, services per conception, corpus luteum diameter (mean \pm SEM), first service conception and proportion of multiparous lactating dairy cows with a corpus luteum at day 30 postpartum, and with subclinical endometritis according to whether or not they were supplemented with clinoptilolite.

\begin{tabular}{lccccc}
\hline Variables & \multicolumn{2}{c}{ Treatment } & \multicolumn{3}{c}{ P-value } \\
\cline { 2 - 6 } & $\begin{array}{c}\text { Clinoptilolite } \\
(\mathrm{n}=42)\end{array}$ & $\begin{array}{c}\text { Control } \\
(\mathrm{n}=35)\end{array}$ & $\mathrm{T}$ & $\mathrm{F}$ & $\mathrm{T} \times \mathrm{F}$ \\
& $23.5 \pm 1.6$ & $27.0 \pm 1.6$ & 0.0759 & 0.6227 & 0.0743 \\
\hline Postpartum intervals to (days) & $76.6 \pm 6.3$ & $75.4 \pm 6.2$ & 0.8620 & 0.3032 & 0.9937 \\
$\quad I^{\text {st }}$ corpus luteum & $109.9 \pm 12.0$ & $144.0 \pm 12.4$ & 0.0224 & 0.0878 & 0.0010 \\
$\quad$ first service & $1.48 \pm 0.19$ & $1.78 \pm 0.18$ & 0.1882 & 0.9177 & 0.0831 \\
$\quad$ conception & $25.9 \pm 1.5$ & $24.0 \pm 1.6$ & 0.3258 & 0.5963 & 0.8708 \\
Number of services per conception & 54.7 & 42.8 & 0.2982 & - & - \\
Corpus luteum diameter (mm) & 58.8 & 52.0 & 0.6019 & - & - \\
Cows with a CL at day 30 (\%) * & 4.7 & 22.8 & 0.0001 & - & - \\
First service conception (\%) & & & & & \\
Subclinical endometritis (\%) & & &
\end{tabular}

$\mathrm{T}$ : treatment; $\mathrm{F}$ : farm; $\mathrm{T}^{\prime} \mathrm{F}$ : treatment ' farm. * proportion of cows with a corpus luteum at day 30 postpartum

Although not significant, cumulative pregnancy rates in the first 90 days postpartum were between 4.7 and 15.7 percentage points greater in CLG than in CG (Fig. 2).

\section{Discussion}

This study aimed to assess the effect of supplementing clinoptilolite to multiparous dairy cows managed in a mountain tropical pasture-based system on reproductive performance and uterine health. The results showed that addition of clinoptilolite to the diet significantly reduced the interval calving to conception, the percentage of uterine PMN leukocytes, and the proportion of cows with subclinical endometritis. Clinoptilolite may have improved uterine health and reduced the interval to conception through two mechanisms: 1) modifying ruminal physiology (Urías-Estrada et al., 2017) and as a consequence 
improving the metabolic status (Karatzia et al., 2013), and 2) strengthening the immune system of cows (Ural, 2014; Đuričić et al., 2017; Đuričić et al., 2020).

In the current study, body condition did not differ between groups along the first 35 days postpartum, indicating that addition of clinoptilolite in the diet did not improve the energetic balance of cows in the early postpartum. In a previous study, supplementation of a greater dose of clinoptilolite (180 and 270 $\mathrm{g} / \mathrm{cow} /$ day during 60 days before and 45 days after calving, respectively) to the basal diet improved body condition score in multiparous lactating dairy cows managed under similar conditions to the current study (Garzón et al., 2017). In another study, clinoptilolite supplementation (200 g daily) increased body condition score and blood serum concentration of glucose and acetoacetate, and decreased blood serum concentration of ketone bodies, without affecting milk production (Karatzia et al., 2013). However, both studies were conducted in animals (cows and heifers respectively) in which supplementation with clinoptilolite began between 210 to 225 days of gestation, and exhibited a considerably better body condition at calving.

Although the follicular categories were, in general, similar between treatments, ultrasonographic monitoring determined larger follicles in CLG cows. That finding is consistent with numerical trends in later reproductive variables, such as interval to the first corpus luteum, first service conception rate, proportion of cows with a corpus luteum at day 30 postpartum (these variables did not differ statistically), and the significant difference in open days.

Rapid resumption of cyclic ovarian activity after calving is essential to achieve maximum productivity in the dairy herd (Giordano et al., 2012). In this study, resumption of ovarian cyclicity determined by detection of a corpus luteum by ultrasound in the first 35 days after calving was slightly faster in CLG than CG, although diameter of luteal tissue did not vary between groups. As a reference, proportion of cows with a corpus luteum at day 30 after calving was around 12 percentage points greater in CLG than in $C G(P=0.2982)$. No published data were found on the effect of the addition of clinoptilolite in the basal diet on resumption of ovarian cyclicity, as determined in the present study. However, supplementation of dairy heifers with $200 \mathrm{~g}$ of clinoptilolite reduced the interval to the first postpartum estrous by 6 days (Karatzia et al., 2013). Based on the detection of a follicle $\geq 10 \mathrm{~mm}$ as indicative of resumption of ovarian activity, Garzón et al. (2017) found that supplementation of multiparous dairy cows with clinoptilolite (180 and $270 \mathrm{~g} / \mathrm{cow} /$ day during the dry period and early postpartum respectively) doubled the proportion of cows that returned to ovarian activity within a period of time 45 days after calving.

In the aforementioned studies, the supplementation of greater amounts of clinoptilolite began at least 60 days before the expected date of calving, whereas in our study it began 30 days before parturition with 50 $\mathrm{g} / \mathrm{cow} /$ day of clinoptilolite. The addition of clinoptilolite prior to parturition was intended to promote the adaptation of this additive in the rumen. The considerably lower amount added to the diet during this period in the current study may explain the lack of effect on body condition and on resumption of reproductive cyclicity and calving to first service interval. It is reasonable that adding a larger amount of clinoptilolite over a longer period before parturition may have an effect on specific aspects of the body 
physiology leading to an energy balance favorable to reproductive function, as demonstrated by Karatzia et al. (2013) and Garzón et al. (2017). It is well known that a positive energy balance and a suitable postpartum body condition influence reproductive performance (Spicer et al., 1990; Butler and Smith, 1989). Specific traits included increased circulating concentrations of progesterone, estradiol and $\mathrm{LH}$, enhanced number and quality of oocytes retrieved by ultrasound-guided transvaginal aspiration (Kendrick et al., 2010), reduced intervals to first estrus and increased conception rate (Beam and Butler, 1999; Butler, 2003).

Addition of clinoptilolite significantly decreased the number and percentage of uterine PMN leukocytes. In a similar study in the southern Ecuadorian Andes (Garzón et al., 2017), cows supplemented with clinoptilolite had a significantly lower percentage (3.4\%) of PMN leukocytes than the control group $(22.3 \%)$, which agrees with findings in this study. Moreover, clinoptilolite significantly reduced the proportion of cows with subclinical endometritis, a finding not previously reported in cows. In a different experimental context, addition of clinoptilolite to lactating dairy cows decreased somatic cell count (Ural, 2014), and numbers of bacterial causing mastitis, as well as the risk of intramammary infection compared to control group (Đuričić et al., 2017; Đuričić et al., 2020).

Bacteria colonizing the uterus during and immediately after calving, many of them pathogenic (Williams et al., 2007), adhere to endometrium, and even penetrate deeper layers, causing varying degrees of infertility (Lazzari et al., 2011). Likewise, pathogenic bacteria produce endotoxins that affect reproductive performance of cows in various ways (Suzuki et al., 2001; Williams et al., 2001; Williams et al., 2008; Lavon et al., 2008), several of them related to the production of inflammatory mediators (Williams et al., 2007).

Clinoptilolite has been shown to have antibacterial, antioxidant and anti-inflammatory and immunomodulatory effects in various species of mammals (review by Valpotić et al., 2017; Pavelić et al., 2018; Mastinu et al., 2019). For instance, in mice, adding clinoptilolite in the food ration for 5 months reduced cell death induced by reactive oxygen species (ROS) and production of ROS in mitochondria (Montinaro et al., 2013). In weaned pigs, supplementing clinoptilolite in the diet reduced total bacteria in jejunum and diarrhea severity, and increased recruitment of CD54RA ${ }^{+}$cells (Valpotić et al., 2017). Addition of $200 \mathrm{~g}$ of clinoptilolite for 70 days in cows (E. coli-vaccinated on day 210-240 of gestation) increased specific antibody titers against E. coli in their serum and colostrum and in the serum of their calves (Karitzia et al., 2010). Feeding newborn calves with 3 liters of maternal colostrum containing 5 $\mathrm{g} /$ liter of clinoptilolite caused $50 \%$ greater IgG levels at 24 and $48 \mathrm{~h}$ after birth than control calves (Fratric et al., 2005). In poultry, addition of 2 or $3 \%$ of clinoptilolite in the diet (for 40 days) to broiler chicks increased percentages of $\mathrm{T}$ lymphocytes expressing CD4 + CD25+, and B lymphocytes expressing BU-1 + and MHC Class II + molecules, and in the CD4:CD8 ratio (Jarosz et al., 2017). Although the precise mechanism by means clinoptilolite increases immune activity in animals is unknown yet, this body of evidence clearly demonstrates the immune-stimulating property of this compound. 
In light of the experimental evidence cited above, and results of the current study, it is likely that cows on CG diet had a weaker immune system, and as a consequence, had a greater number and percentage of uterine PMN leukocytes. Therefore, more of them had percentages of uterine PMN leukocytes indicative of subclinical endometritis.

According to evidence discussed above, it is plausible that the better reproductive performance achieved by CLG cows occurred due to the antioxidant and immune-stimulating properties of clinoptilolite. As a consequence, a healthier uterine environment favored clinoptilolite-supplemented cows to became pregnant earlier, with a first service conception rate 7 percentage points greater and 0.3 fewer inseminations than CG group. Moreover, CLG cows reached an accumulated pregnancy at 90 days postpartum 15.7 percentage points greater than CG. Ninety days postpartum is a critical time by which the reproductive goal of one calf and one lactation per year is attained (Perea et al., 2001). Each additional day to achieve pregnancy has a significant economic cost for dairy farms (De Vries, 2006). Thus, addition of clinoptilolite to the feed ration from prepartum and during postpartum may be implemented as a routine strategy to improve uterine health and reproductive efficiency in dairy farms.

In conclusion, this study showed that the daily addition of clinoptilolite in the diet prior to calving (50 $\mathrm{g}$ daily) and up to 60 days postpartum (200 g daily) had beneficial effects on reproduction by reducing the prevalence of subclinical endometritis and open days in multiparous lactating dairy cows managed in a mountain tropical pasture-based system.

\section{Declarations}

\section{Author contribution}

JG, AG and GL conceived and designed research. FS and JZ conducted experiment and wrote original draft. GC and FQ contributed new reagents or analytical tools. FP: analyzed data, reviewed and edited the manuscript.

\section{Acknowledgements}

The authors thank the Department of Research and Development of 'La Colina Cia. Ltda.' for contributing to this research. The authors also thank Dr. Keith Inskeep, Division of Animal and Nutritional Sciences, West Virginia University, for reading and correcting this manuscript.

\section{Funding information}

This study was supported by the Research Directorate of the University of Cuenca (DIUC), Ecuador, throughout project DIUC-XIV-2016-022.

\section{Conflict of interest}

The authors declare to have no conflict of interest. 


\section{Data availability}

Data will be made available on reasonable request.

\section{References}

1. Beam SW, Butler WR. 1999. Effects of energy balance on follicular development and first ovulation in postpartum dairy cows. Journal of Reproduction and Fertility Supplement, 54, 411-424.

2. Bromfield JJ, Santos JE, Block J, Williams RS, Sheldon IM. 2015. Uterine infection: linking infection and innate immunity with infertility in the high-producing dairy cow. Journal of Animal Science, 93, 2021-2033.

3. Butler WR, Smith RD. 1989. Interrelationships between energy balance and postpartum reproductive function in dairy cattle. Journal of Animal Science, 72, 767-783.

4. Butler WR. 2003. Energy balance relationships with follicular development, ovulation and fertility in postpartum dairy cows. Livestock Production Science, 83, 211-218.

5. Drackley JK. 1999. Biology of dairy cows during the transition period: the final frontier? Journal of Dairy Science, 82, 2259-2273.

6. Drackley JK, Cardoso FC. 2014. Prepartum and postpartum nutritional management to optimize fertility in high-yielding dairy cows in confined TMR systems. Animal, 8(Suppl. 1), 5-14.

7. Đuričić $D$, Vince S, Lojkić $M$, Jelušić $S$, Turk R, Valpotić $H$, Gračner $D$, Maćešić $N$, Folnožić I, Šostar Z, Samardžija M. 2020. Effects of dietary clinoptilolite on reproductive performance, serum progesterone and insulin-like growth factor- 1 concentrations in dairy cows during pregnancy and lactation. Polish Journal of Veterinary Sciences, 23, 69-75.

8. Edmonson AJ, Lean IJ, Weaver LD, Farver T, Webster G. 1989. A body condition scoring chart for Holstein dairy cows. Journal of Dairy Science, 72, 68-78.

9. Fratric N, Stojić V, Janković D, Šamanac H, Gvozdić D. 2005. The effect of a clinoptilolite based mineral adsorber on concentrations of immunoglobulin $\mathrm{G}$ in the serum of newborn calves fed different amounts of colostrum. Acta Veterinaria (Beograd) 55: 11-21.

10. Garzón JP, Barrera VH, Galarza DA, Soria ME, Rodríguez DF, López GE, Marini P.R. 2017. Efecto de la zeolita sobre retorno de la actividad ovárica, involución y salud uterina en vacas lecheras postparto criadas en pastoreo. Livestock Research and Rural Development, 29, 3-7.

11. Giordano JO, Kalantari AS, Fricke PM, Wiltbank MC, Cabrera VE. 2012. A daily herd Markov-chain model to study the reproductive and economic impact of reproductive programs combining timed artificial insemination and estrus detection. Journal of Dairy Science, 95, 5442-5460.

12. Inchaisri C, Jorritsma R, Vos PL, Van der Weijden GC, Hogeveen H. 2010. Economic consequences of reproductive performance in dairy cattle. Theriogenology, 74, 835-846

13. Ivkovic S, Deutsch U, Silberbach A, Walraph E, Mannel M. 2004. Dietary supplementation with the tribomechanically activated zeolite clinoptilolite in immunodeficiency: effects on the cellular immune 
system. Advances in Natural Therapy, 21, 1-14.

14. Jarosz L, Stepien-Pysniak D, Gradzki Z, Kapica M, Gacek A. 2017. The effect of feed supplementation with Zakarpacki zeolite (clinoptilolite) on percentages of $\mathrm{T}$ and $\mathrm{B}$ lymphocytes and cytokine concentrations in poultry. Poultry Science, 96, 2091-2097.

15. Karatzia MA, Katsoulos PD, Karatzia H. 2013. Diet supplementation with clinoptilolite improves energy status, reproductive efficiency and increases milk yield in dairy heifers. Animal Production Science, 53, 234-239.

16. Karatzia MA. 2010. Effect of dietary inclusion of clinoptilolite on antibody production by dairy cows vaccinated against Escherichia coli. Livestock Science, 128, 149-153

17. Kasimanickam R, Duffield TF, Foster RA, Gartley CJ. 2004. Endometrial cytology and ultrasonography for the detection of subclinical endometritis in postpartum dairy cows. Theriogenology, 62, 9-23.

18. Kendrick KW, Bailey TL, Garst AS, Pryor AW, Ahmadzadeh A, Akers RM, Eyestone WE, Pearson RE, Gwazdauskas FC. 2010. Effects of energy balance on hormones, ovarian activity, and recovered oocytes in lactating Holstein cows using transvaginal follicular aspiration. Journal of Dairy Science, 82, 1731-1741.

19. Lacasse P, Vanacker N, Ollier S, Ster C. 2018. Innovative dairy cow management to improve resistance to metabolic and infectious diseases during the transition period. Research in Veterinary Science, 116, 40-46.

20. Lavon Y, Leitner G, Goshen T, Braw-Tal R, Jacoby S, Wolfenson D. 2008. Exposure to endotoxin during estrus alters the timing of ovulation and hormonal concentrations in cows. Theriogenology, 70, 956967.

21. Lazzari G, Duchi R, Colleoni S, Baldazzi L, Benedetti V, Galli ALuini M, Ferrari M, Galli C. 2011. Le patologie uterine cliniche e subcliniche come causa di infertilità nelle bovine da latte: Studio epidemiologico in due allevamenti della regione Lombardia. Large Animal Review, 17,:43-47.

22. LeBlanc SJ, Duffield TF, Leslie KE, Bateman KG, Keefe GP, Walton JS, Johnson WH. 2020. Defining and diagnosing postpartum clinical endometritis and its impact on reproductive performance in dairy cows. Journal of Dairy Science, 85, 2223-2236.

23. Little MW, O'Connell NE, Welsh MD, Mulligan FJ, Ferris CP. 2017. Concentrate supplementation of a diet based on medium-quality grass silage for 4 weeks prepartum: Effects on cow performance, health, metabolic status, and immune function. Journal of Dairy Science, 100, 4457-4474.

24. Mallek Z, Fendri I, Khannous L, Ben Hassena A, Traore Al, AyadiM.A., Gdoura, R. 2012. Effect of zeolite (clinoptilolite) as feed additive in Tunisian broilers on the total flora, meat texture and the production of omega 3 polyunsaturated fatty acid. Lipids in Health and Disease, 11, 1-7.

25. Mastinu A, Kumar A, Maccarinelli G, Bonini SA, Premoli M, Aria F, Gianoncelli A, Memo M. 2019. Zeolite clinoptilolite: therapeutic virtues of an ancient mineral. Molecules, 24, 1517; doi:10.3390/molecules24081517.

26. Montinaro M, Uberti D, Maccarinelli G, Bonini SA, Ferra-ri-Toninelli G, Memo M. 2013. Dietary zeolite supplementation reduces oxidative damage and plaque generation in the brain of an Alzheimer's 
disease mouse model. Life Sciences, 92, 903-910.

27. Mulligan FJ, Doherty ML. 2008. Production diseases of the transition cow. Veterinary Journal, 176, 3-9.

28. Osorio JS, Trevisi E, Li C, Drackley JK, Socha MT, Loor JJ. 2016. Supplementing Zn, Mn, and Cu from amino acid complexes and Co from cobalt glucoheptonate during the peripartal period benefits postpartal cow performance and blood neutrophil function. Journal of Dairy Science, $99,1868-$ 1883.

29. Pascottini OB, LeBlanc SJ. 2020. Modulation of immune function in the bovine uterus peripartum. Theriogenology, 150, 193-200.

30. Pavelic SK, Medica JS, Gumbarevic D, Filoševic A, Pržulj N, Pavelic Krešimir. 2018. Critical review on zeolite clinoptilolite safety and medical applications in vivo. Frontiers in Pharmacology, 9, 1350. doi:10.3389/fphar.2018.01350.

31. Pinedo PJ, De Vries A, Webb DW. 2010. Dynamics of culling risk with disposal codes reported by Dairy Herd Improvement dairy herds. Journal of Dairy Science, 93, 2250-2261.

32. Perea FP, Soto E, González C. 2002. Días vacíos y producción de leche en vacas mestizas [Opern days and milk production in crossbred cows]. In: Avances en la Ganadería de Doble Propósito [Advances in Dual Purpose Cattle]. González-Stagnaro C., Soto Belloso, E., Ramírez Iglesia., L (Ed). Fundación GIRARZ. Ediciones Astro Data S.A. Cap. XXVI, 401-416.

33. Quintela LA, Fernández MV, Becerra JJ, Barrio MB, García PJ, Martínez IP. 2018. Subclinical Endometritis in Dairy Cattle. In: New Insights into Theriogenology. DOI: 10.5772/intechopen.80229

34. Roche JR, Burke CR, Crookenden MA, Heiser A, Loor JL, Meier S, Mitchell MD, Phyn CVC, Turner SA. 2017. Fertility and the transition dairy cow. Reproduction, Fertility and Development, 30, 85-100.

35. Sordillo LM, Contreras GA, Aitken SL. 2009. Metabolic factors affecting the inflammatory response of periparturient dairy cows. Animal Health Research Reviews, 10, 53-63.

36. Spicer LJ, Tucker WB, Adams GD. 1990. Insulin-like growth factor-i in dairy cows: relationships among energy balance, body condition, ovarian activity, and estrous behavior. Journal of Dairy Science, 73, 929-937.

37. Suzuki C, Yoshioka K, Iwamura S, Hirose H. 2001. Endotoxin induces delayed ovulation following endocrine aberration during the proestrous phase in Holstein heifers. Domestic Animal Endocrinology, 20, 267-278.

38. Ural DA. 2014. Efficacy of clinoptilolite supplementation on milk yield and somatic cell count. MVZ Córdoba, 19, 4242-4248

39. Urías-Estrada JD, López-Soto MA, Barreras A, Aguilar-Hernández JA, González-Vizcarra VM, EstradaAngulo A, Zinn RA, Mendoza GD, Plascencia A. 2017. Influence of zeolite (clinoptilolite) supplementation on characteristics of digestion and ruminal fermentation of steers fed a steamflaked corn-based finishing diet. Animal Production Science, 58, 1239-1245.

40. Valpotic H, Terzic S, Vince S, Samardzija M, Turk R, Lackovic G, Habrun B, Djuricic D, Sadikovic, M, Valpotic I. 2016. In-feed supplementation of a clinoptilolite favorably modulates intestinal and 
systemic immunity and some production parameters in weaned pigs. Veterinary Medicine, 61, 317327.

41. Valpotić $H$, Gračner $D$, Turk R, Đuričić D, Vince S, Folnožić I, Lojkić $M$, Žaja IŽ, Bedrica L, Maćešić N, Getz I, Dobranić T, Samardžija M. 2017. Zeolite clinoptilolite nonporous feed additive for animals of veterinary importance: potentials and limitations. Periodicum Biologorum, 119, 159-172.

42. Williams CY, Harris TG, Battaglia DF, Karsch FJ, Viguié C. 2001. Endotoxin inhibits pituitary responsiveness to gonadotropin-releasing hormone. Endocrinology, 142, 1915-1922.

43. Williams EJ, Fischer DP, Noakes DE, England GCW, Rycroft A, Dobson H, Sheldon IM. 2007. The relationship between uterine pathogen growth density and ovarian function in the postpartum dairy cow. Theriogenology, 68, 549-59.

44. Williams EJ, Sibley K, Miller AN, Lane EA, Fishwick J, Nash DM, Herath S, England GC, Dobson H, Sheldon IM. 2008. The effect of Escherichia coli lipopolysaccharide and tumour necrosis factor alpha on ovarian function. American Journal of Immunology and Reproduction, 60, 462-473.

45. Wu QJ, Zhou YM, Wu YN, Zhang LL, Wang T. 2013. The effects of natural and modified clinoptilolite on intestinal barrier function and immune response to LPS in broiler chickens. Veterinary Immunology and Immunopathology, 153, 70-76.

46. Zarkovic N, Zarkovic K, Kralj M, Borovic S, Sabolovic S, Blazi MP, Cipak A, Pavelic K. 2003. Anticancer and antioxidative effect of micronized zeolite clinoptilolite. Anticancer Research, 23, 1589-1596.

47. Zebel Q, Ghareeb K, Humer E, Metzler-Zebeli BU, Besenfelder U. 2015. Nutrition, rumen health and inflammation in the transition period and their role on overall health and fertility in dairy cows. Research in Veterinary Science, 103, 126-136.

\section{Figures}


- Clinoptilolite $\square$ Control

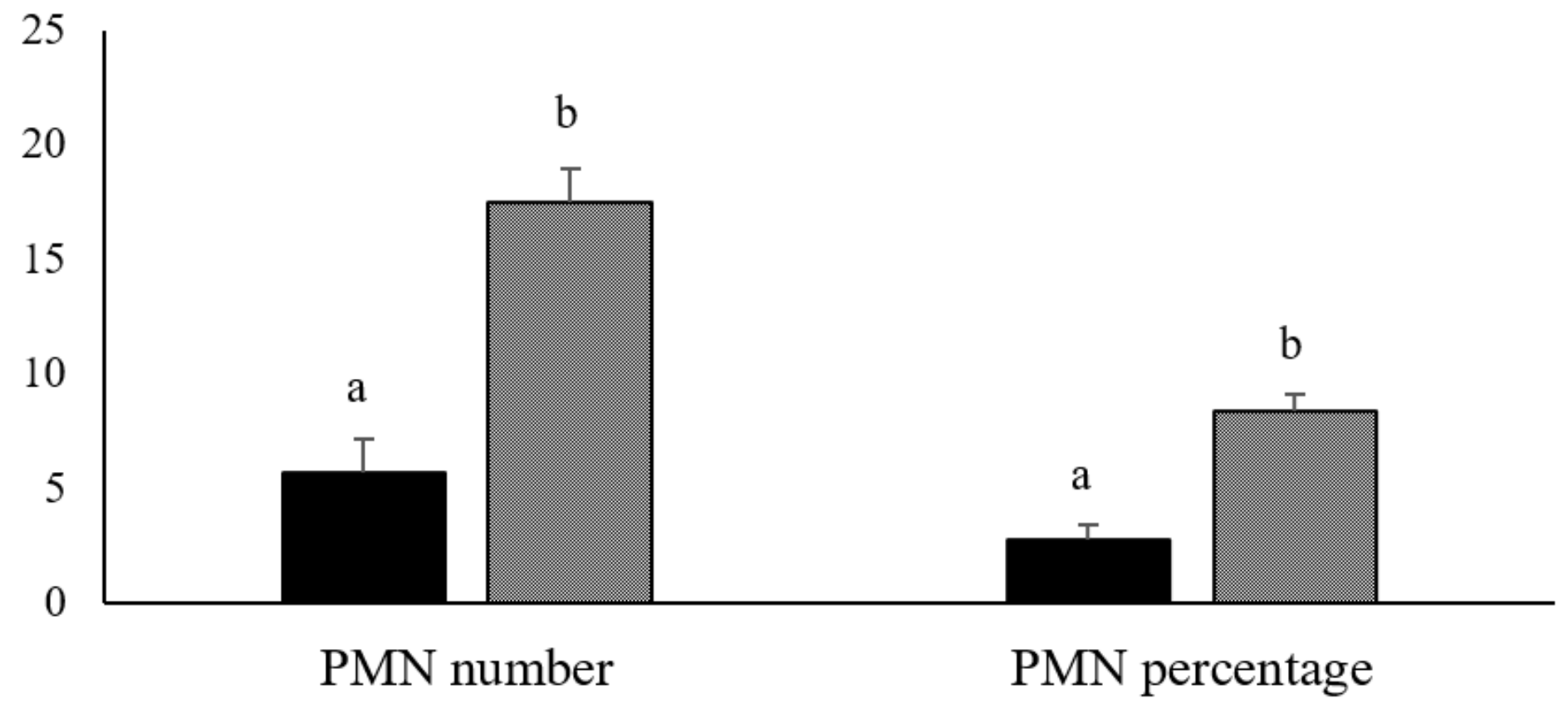

Figure 1

Number and percentages of uterine PMN leukocytes in the early postpartum in multiparous lactating cows according to whether or not they were supplemented with clinoptilolite. a-b $\mathrm{P}<0.0001$.

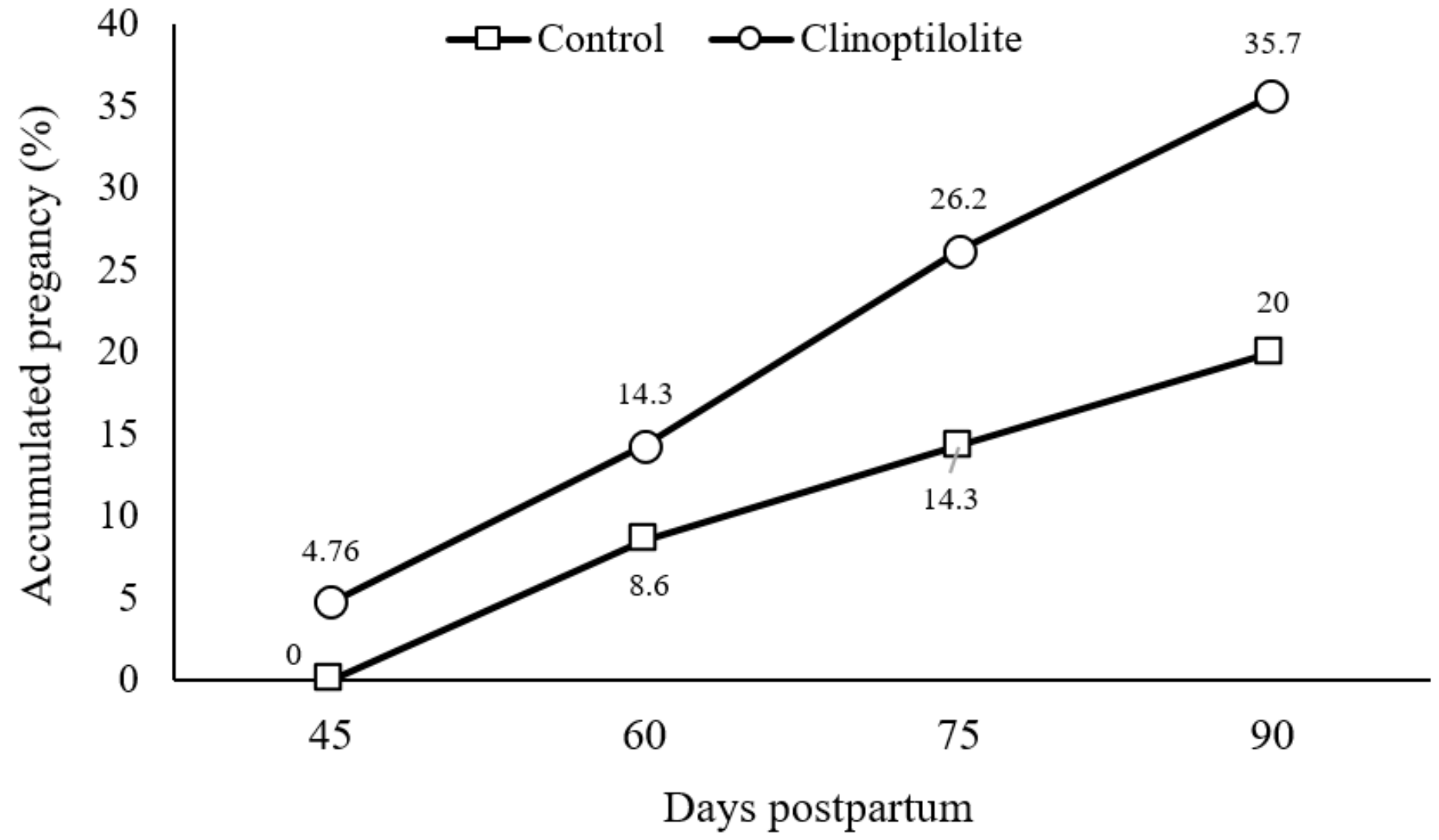


Figure 2

Accumulated pregnancy at $45,60,75$ and 90 days postpartum in multiparous lactating dairy cows according to whether or not they were supplemented with clinoptilolite. 